\title{
Privilege travels: migration and labour market outcomes of Southern Italian graduates
}

\author{
Diana Roxana Galos ${ }^{*}$ (D
}

\section{${ }^{*}$ Correspondence:}

diana.galos@uni-konstanz.de University of Konstanz, Universitätsstraße 10,

78464 Konstanz, Germany

\begin{abstract}
This paper contributes to the literature on social stratification by analysing the role of internal migration as a possible channel for the intergenerational transmission of inequality. While internal migration is associated with social mobility, it can also be used as a strategy of status maintenance among graduates from privileged backgrounds. The aim of this paper is to scrutinize whether internal migration for study or work, and subsequent labour market outcomes, are associated with social origins. Using a rich administrative and survey data set on a cohort of Italian graduates, findings show a substantive effect of social origins on graduates' migration for study but not on migration for work. Finally, the results also more tentatively indicate that migration for study is one relevant path connecting social origins and income, thus emphasizing how privilege is not bound to place, but travels.
\end{abstract}

Keywords: Migration, Social origins, Graduates, Labour market, Inequality

\section{Introduction}

In Italy, an individual's outcome in the labour market reflects sharp regional socioeconomic differences (Dotti et al., 2013; Panichella, 2013). These differences have been accentuated in the aftermath of the Second World War (De Rita, 2002) and they are so substantial that some scholars have referred to the existence of "three Italies": North, Center, and South (Bagnasco, 1997). In search for opportunities, individuals from the less-developed South have migrated to the wealthier North and Center. ${ }^{1}$ As a result, internal migration has increased individuals' chances in the labour market (Fields, 1976; Smith et al., 2015; White, 2016), yet, in contrast to the inter-regional migrants from the 1950s, the current Italian migrants are highly educated (Ciriaci, 2005). This aspect has attracted the attention of sociologists and policymakers as it could lead to brain drain, which refers to the migration of highly educated individuals from poorer to richer regions in terms of educational and employment opportunities (Attanasio \& Enea, 2019; Ciriaci, 2014; Mocetti \& Porello, 2010; Piras, 2005; Ruiu et al., 2019).
${ }^{1}$ The "North" and the "Center" of Italy is considered together and it is labelled as the "North". The "South" of Italy includes the following regions: Abruzzo, Apulia, Basilicata, Campania, Calabria, Molise, Sicily and Sardinia.

(c) The Author(s) 2022. Open Access This article is licensed under a Creative Commons Attribution 4.0 International License, which permits use, sharing, adaptation, distribution and reproduction in any medium or format, as long as you give appropriate credit to the original author(s) and the source, provide a link to the Creative Commons licence, and indicate if changes were made. The images or other third party material in this article are included in the article's Creative Commons licence, unless indicated otherwise in a credit line to the material. If material is not included in the article's Creative Commons licence and your intended use is not permitted by statutory regulation or exceeds the permitted use, you will need to obtain permission directly from the copyright holder. To view a copy of this licence, visit http:// creativecommons.org/licenses/by/4.0/. 
In the context of expansion and differentiation of higher education (Lucas, 2001), young individuals mainly consider two migration strategies: when enrolling at a nonlocal university to pursue higher education or for work (after completing their studies at a local university). In the case of Italy, internal migration from the South to the North has been motivated by the quality and prestige of universities (Ciriaci, 2014; Impicciatore \& Tosi, 2019; Impicciatore \& Tuorto, 2011) and also the dynamic labour market (Brunello \& Cappellari, 2008). In addition, the migration of young and highly educated individuals might also be incentivized by the fact that migration in the early stages of a professional career is associated with financial and social capital accumulation. This is the case of Italy and other European countries for both international (Assirelli et al., 2018; Kahanec \& Fabo, 2013) and internal migration (Capuano, 2012; Dotti et al., 2013).

However, it is likely that individuals' decision to migrate does not only reflect a personal preference but is also influenced by their family background (Stark \& Bloom, 1985). More specifically, the family background might play a role both in individuals' decision to migrate in the first place and in their labour market outcomes after migration. From this perspective, migration could be considered a strategy that involves not only the migrants but also their families. Yet, the role of family background in the migration process has been understudied, even though it is likely that social origin is a relevant predictor of the decision to migrate and of subsequent outcomes (Impicciatore \& Tosi, 2019; Panichella, 2013).

To address this lacuna, this paper makes two key contributions. First, it studies the effect of social origins, measured by parental education, on the probability of migrating for study and work to the North and Center of Italy for graduates originating in the South. Parental education is of particular importance in the migration process as individuals with highly educated parents might not only be more likely to graduate from university but also to be better informed about the different degree choices. The literature yields two countervailing hypotheses in this regard. On the one hand, individuals from a privileged background ${ }^{2}$ possess social, economic, and cultural resources (Bourdieu, 1984; Erikson \& Jonsson, 1998) that are useful in the migration process. Thus, a privileged background is likely to increase the probability of migration (Ballarino \& Panichella, 2021; Impicciatore \& Tosi, 2019; Panichella, 2013). However, on the other hand, a privileged background might provide less incentive for individuals to migrate as their parental resources could be even more useful in the place of origin (Capuano, 2012). Hence, individuals from a less privileged social background may be more likely to migrate than individuals from a privileged background as they lack these resources and, therefore, have higher incentives to migrate to improve their social standing.

Second, this paper investigates whether internal migration mediates the relationship between social origins and individuals' labour market outcomes. In other words, whether the long and extended reach of social origins continue to persist even when graduates leave their geographical region. As the labour market outcomes of highly educated individuals is still stratified by social origins (Bernardi \& Ballarino, 2016; Witteveen \& Attewell, 2020), the question is whether internal migration might be a channel

2 Throughout the paper, the terms "privileged background" and "socioeconomically advantageous background" are used interchangeably. 
of the intergenerational reproduction of inequality on the labour market. As this paper focuses on income and access to professional and managerial occupations (EGP I-II), it complements the previous research that studies employment stability (Panichella, 2013) and access to upper class, avoidance of working-class and agricultural occupations (Ballarino \& Panichella, 2021) as measures for occupational attainment in the migration process.

Moreover, compared to other studies that focused on graduates as an overall category (Impicciatore \& Tosi, 2019), this paper considers an under-studied category of migrants, namely, advanced degree holders, individuals who graduated from Master's or long Bachelor's degrees. ${ }^{3}$ Compared to Bachelor's degree holders, the individuals with Master's and long Bachelor's degrees differ in motivation, ambition, and skills acquired. Therefore, considering both groups in one homogeneous category would produce biased conclusions (Torche, 2011). It is relevant to focus on this category of individuals as, besides doctorate students, they are the most educated individuals in society. Therefore, scrutinizing the effect of social origins on their opportunity to migrate and their employment outcomes after migration is crucial in revealing how social background and geographical inequalities pertain to highly educated individuals. It is possible to focus on this understudied category using a rich data set (AlamaLaurea) that combines administrative and survey data of Italian graduates, 5 years after graduation.

\section{Social origins and internal migration}

One of the main drivers of internal migration is individuals' access to better employment opportunities than in their place of origin while being aware of the costs and benefits associated with their migration decision (Arango, 2000). Yet, not everyone has the same opportunities for migrating. Even though individuals might have similar reasons to migrate for study or work, social origins could play a central role in their actual propensity to migrate. This might be the case as different social backgrounds are associated with various resources available in the migration process but also perceived benefits of migration.

Regarding the availability of resources, individuals from socioeconomically advantaged backgrounds possess more financial, cultural and social capital compared to individuals from socioeconomically disadvantaged backgrounds (Bourdieu, 1984; Erikson \& Jonsson, 1998). As these resources are useful in the migration process (Carling, 2002), a privileged social background might stimulate internal migration for study and work. First, the financial capital of privileged families might influence individuals' propensity to migrate for study and work. Yet, financial capital might weigh differently for various migratory strategies. Financial capital is relevant, especially concerning migration for study as it entails both university fees and living costs (Faini et al., 1997; Panichella, 2013). This might be particularly relevant in the case of Italy. In contrast with the migrants from the 1950s who migrated from the South to the North of Italy and sent money back home (remittances), the family background is likely to play a more pronounced role in the case of the recent migrants who migrate for study (Ambrosini,

\footnotetext{
${ }^{3}$ The term "graduates" is used to refer to this category.
} 
2005). In the case of migration for work, financial capital is likely to be less relevant as graduates might already have a job offer at the moment of migration. Thus, the risk and the cost of migration for work is reduced and family background might be less pertinent as in the case of migration for study.

Second, the social capital might also be useful in the internal migration process as individuals from privileged backgrounds can rely on the social networks of their families. A privileged family background might provide access to "instrumental networks" (Barbieri, 2003) that are particularly helpful in navigating the educational and career options available both inside and outside of ones' region. As social networks can be used as an informal way of recruitment, especially for highly educated individuals (Di Stasio \& Gërxhani, 2015), it is likely that graduates from privileged backgrounds might benefit from their parents' connections even outside their geographical regions. These networks might be useful when graduates migrate to new regions as the unfamiliarity with the educational system and the local labour market pose challenges.

Third, graduates from privileged backgrounds might also take advantage of their parental education-i.e., cultural capital-in the migration process. Compared to lower educated parents, highly educated parents have a better knowledge of the higher education system as they have navigated it themselves (Bukodi \& Goldthorpe, 2013; Gambetta, 1987). Therefore, as highly educated parents are aware of the qualitative differences within tertiary education that are associated with favourable labour market outcomes (Lucas, 2001), they might encourage their children to study outside of their region to access prestigious universities or fields of study on high demand in the labour market.

In short, financial, social, and cultural resources associated with a privileged background might be translated into a source of advantage in individuals' propensity to migrate. Migration is an investment that presents potential benefits and risks as not all migration spells have favourable labour market returns. Individuals from a privileged background might not only use their resources to pursue their migration strategies but also have a "safety net" on which to fall back if migration does not bring the desired outcomes. Considering the resources that individuals from a privileged background possess, we can hypothesize that individuals from a privileged background are more likely to migrate for study and work than individuals from a less privileged background (H1).

However, regarding the perceived benefits related to migration, individuals from a less privileged background might also have aspiration to migrate to regions with a more vibrant labour market. Aspiration to migrate (the belief that migration is preferable compared to non-migration) emerges within a socioeconomic environment (Carling \& Schewel, 2018). Following a cost-benefits analysis (Arango, 2000), individuals from a less privileged background are likely to migrate if the perceived benefits are believed to be greater than migration costs. For example, as migration for study is related to good quality universities and increased employment opportunities (Ciriaci, 2005; Wilson, 1985), ${ }^{4}$ even if individuals from less privileged background possess limited resources, they might perceive migration as a strategy for improving their social standing (Blau \&

\footnotetext{
${ }^{4}$ This finding is confirmed both in countries that have a stratified education system such as the United States (Black \& Smith, 2004) and the United Kingdom (Chevalier \& Conlon, 2003) but also in countries with a less differentiated higher education system such as Italy (Brunello \& Cappellari, 2008).
} 
Duncan, 1967; DaVanzo, 1981). Hence, they might use internal migration as a strategy to compensate for their already existing penalty on the labour market associated with their lower socioeconomic standing. Considering the perceived benefits of migration, we can hypothesize that individuals from a less privileged background are more likely to migrate for study and work compared to individuals from a privileged background (H2).

\section{Internal migration as status maintenance?}

Individuals from privileged backgrounds might migrate as a strategy of status maintenance to preserve their social standing in the labour market. According to the relative risk aversion theory, parents from different socioeconomic backgrounds have the same underlying aspirations for their children: to acquire a class position at least as advantageous as their own (Boudon, 1974; Breen \& Goldthorpe, 1997). Yet, to avoid downward mobility, individuals from privileged backgrounds have the pressure to achieve a higher social position compared to their peers from less privileged backgrounds. Thus, as individuals take decisions in terms of gains, losses and neutral outcomes (Kahneman \& Tversky, 1984), migration decisions might have different weight for individuals from various social origins.

In a region with limited employment opportunities, it is more difficult for individuals from privileged backgrounds to preserve their social standing in terms of occupation and income. Hence, internal migration might be used as a strategy to guarantee the maintenance of advantaged positions in the labour market of graduates from privileged backgrounds. As a socioeconomically advantaged background is associated with financial, social and cultural resources, these can be used not only to facilitate the migration process but also to enhance the employment outcomes related with graduates' migration. Thus, we can hypothesize that the effect of social origins on income and occupations is mediated by migration for study (H3.1) and migration for work (H3.2).

Figure 1 illustrates the two models of analysis that are considered in this paper. Model A displays the so-called origin-education-destination "triangle" $\left(\mathrm{O}^{\mathrm{E}} \mathrm{D}\right)$ that represents the underlying processes behind the intergenerational reproduction of inequality (Blau \& Duncan, 1967).

On the left-hand side, it is the social origins that is measured by parental education and on the right-hand side, it is the social destination that is measured by two labour market outcomes (access to professional and managerial occupations and income, respectively). Both social origins and destination are measured 5 years after graduation. As the $\mathrm{O}^{\mathrm{E}} \mathrm{D}$ triangle illustrates, the intergenerational reproduction of inequality occurs through the indirect and direct effect of social origins. The indirect effect of social origins on destination emerges through education as individuals from privileged backgrounds are more likely to attend higher education compared to those from a less privileged background. Consequently, the former is more likely to have better labour market outcomes than the latter. All individuals in this analysis are graduates and education is measured considering a detailed measure of education. The direct effect of social origins on destination refers to all the intergenerational reproduction mechanisms (excluding education), such as cognitive skills, non-cognitive skills, ambition, compensatory advantage, favouritism, employers' discrimination, and inheritance. This paper argues that Model A is incomplete, especially when educational and employment opportunities are unequally 


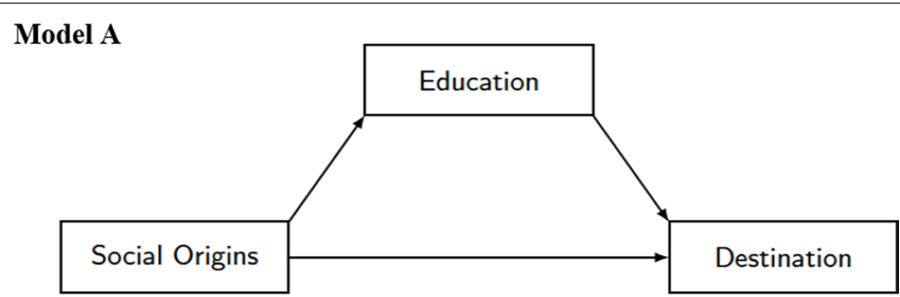

Model B

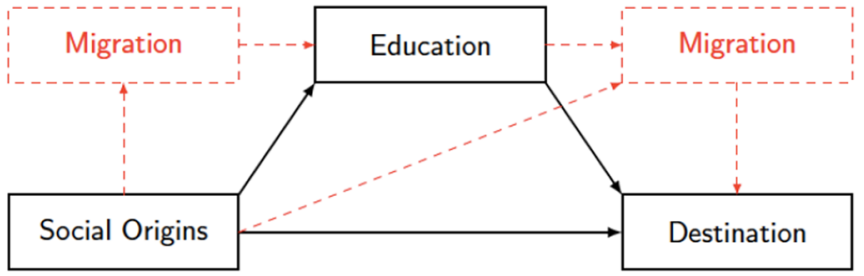

Fig. 1 The origin-education-destination model and its relationship with migration for study and migration for work

distributed across different geographical regions. Building on the first model, Model B introduces migration for study (left side) and migration for work (right side) as possible mediators between social origins and destination.

\section{Data, variables and methods}

Data

This paper uses cross-sectional data from the Italian inter-university consortium AlmaLaurea $^{5}$ that provides representative administrative and survey data of Italian graduates (laurea magistrale and laurea magistrale a ciclo unico). A strength of the administrative data lies in the fact that it includes information on demographics and graduates' educational trajectories for approximately 80 percent of Italian graduates. At the same time, Condizione Occupazionale dei Laureati survey captures graduates' labour market outcomes 5 years after graduation. This paper focuses on the 2010 cohort $(n=61,975)$ that includes students who graduated after the Bologna reform that reshaped the Italian educational system.

The sample is restricted based on geographical residence, age, migration background and field of study. As the focus of this paper is on graduates' strategies of internal migration from the South to the North of Italy, the sample is restricted to graduates who have their residence in the South of Italy during high school $(n=21,249)$. Moreover, the sample considers only respondents younger than 35 years at the time of graduation, because the focus of this paper is young entrants into the labour market. ${ }^{6}$ Graduates who are not native-born Italians are excluded from the sample as their social mobility is likely to be influenced by immigration processes, which are outside the scope of this paper.

\footnotetext{
${ }^{5}$ AlmaLaurea is an inter-university consortium of Italian universities and it has two main aims among other, to assess graduates' satisfaction regarding their studies and to follow-up graduates concerning their labour market outcomes.

6 This is considered the appropriate age ceiling in the analysis as graduates tend to stay longer in the Italian higher educational system (Aina \& Pastore, 2012).
} 
Graduates from the field of defence and security are excluded from the analysis as they usually have different career trajectories from the general population of graduates (AlmaLaurea, 2014). As this paper considers labour market outcomes in terms of $(i)$ occupational attainment and (ii) income, only the employed graduates are included in the analysis. After these restrictions, the sample consists of 11,192 individuals. Figure 6 in the Appendix provides details on sample restriction.

\section{Variables}

The first part of the analysis has one dependent variable that represents graduates' migration behaviour and it has three categories: (1) migration for study (2) migration for work (3) stayers (not migrating). Migration for study and migration for work are mutually exclusive categories that measure whether individuals migrated for study (returned or not) or for work (after studying at a local university). Stayers represents the category of individuals who never migrated (either for study or work) - in other words, individuals who remained in the South of Italy. Figure 2 provides a visual display of the graduates' migration behaviour from the South to the North (and Center) of Italy in the case of migration for study and migration for work.

The second part of the analysis has two dependent variables (1) access to professional and managerial occupation and (2) income. Occupations are measured using the EGP class schema which determines the class position in terms of employment relations (Erikson \& Goldthorpe, 1992). The analysis focuses on the professional and managerial occupations (EGP I-II) as these are occupations with the highest socioeconomic rewards on the labour market that would be targeted by the individuals after graduation. Income is measured using the natural logarithm of the monthly net labour income of the graduates. The income was classified into 13 categories and the width of each interval is 250 euros. As usual, we considered the mid-point value of each class.

The main independent variable is social origins that is measured by parental education: (1) both with a higher education degree, (2) one with a higher education degree (3), one with a high school degree (4) both with less than a high school degree. Without other measures of social origins, such as parental class or status, the analysis is likely to overestimate the effect of parental education but also to underestimate the overall effect of social origins (Bukodi \& Goldthorpe, 2013). Yet, in the case of predicting internal migration among graduates, parental education seems to be of particular importance compared to the other proxies of social origin (Impicciatore \& Tosi, 2019).

The first part of the analysis controls for a range of potentially confounding factors related to the propensity to migrate, including educational trajectory (secondary school, grades secondary school, types of degree, fields of study) and demographic

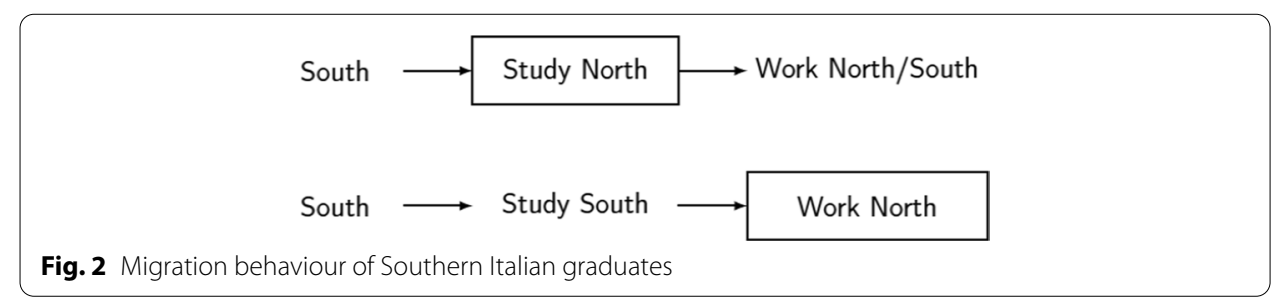


characteristics (gender, age, geographic regions). Secondary school is classified in five categories: classical "liceo", scientific "liceo", other "liceo", technical, vocational, other and foreign "liceo". The final grade in secondary school is a continuous variable that represents the students' performance at the end of their secondary school. The analysis also distinguished between two types of tertiary degrees in terms of length: Master's degree (2 years) and longer Bachelor's degrees ( 5 or 6 years). ${ }^{7}$ We took into account the covariate "field of study", as a potential confounder of the migratory strategy. We used the classification used by AlmaLaurea. ${ }^{8}$ Last but not least, the analysis also controls for the different geographical regions from the South of Italy. The second part of the analysis controls for the same variables as in the first part of the analysis (excluding geographical regions $)^{9}$ but also accounting for grades in university. Final grades upon graduation are classified into three categories from lowest to highest marks: 66-100, 101-110, and 110 cum laude.

\section{Descriptive statistics}

Table 1 shows the descriptive statistics of the sample of Bachelor and Master graduates originating from the South of Italy according to their migration behaviour (stayers, migration for study, migration for work). From the sample of Southern Italian graduates, 50 percent of graduates remain in the South of Italy while 32 percent migrate for study ${ }^{10}$ and 18 percent migrate for work in the North/Center of Italy. Moreover, among women, 52 percent remain in the South of Italy, while 31 percent migrate for study and 17 percent migrate for work. Considering the gender differences, a larger share of men, compared to women, migrate for both study and work in the North (and Center) of Italy. ${ }^{11}$ We can also observe that graduates who have both parents with higher education are more inclined to migrate for study, compared to the graduates who have less educated parents. Regarding fields of study, Agriculture, Architecture, Law and Medicine $^{12}$ are fields of study which have large proportions of stayers and Political Science/ Social Science and Psychology are fields of study which have large proportions of movers for study.

\section{Models}

To address the first question, multinomial logistic models are used to estimate the probability, conditional on a set of individuals characteristics, to be in one of the categories: (1) migration for study (2) migration for work (3) stayers (not migrating). Therefore, a

\footnotetext{
${ }^{7}$ Master's degrees include fields of study such as: Biology/Geography, Natural Science/Mathematics/Physics, Sports Science and Physical Education, Political Science/Social Science and longer Bachelor's degrees study such as: Architecture, Chemistry/Pharmacy, Law, Medicine.

${ }^{8}$ Fields of study are recorded in the AlmaLaurea dataset following a reduced version of the MIUR classification: Agriculture, Architecture, Chemistry/Pharmacy, Economics/Statistics, Sports Science and Physical Education, Biology/ Geography, Law, Engineering, Education, Literature, Linguistics, Medicine, Political Science/Social Science, Psychology and Natural Science/Mathematics/Physics.

${ }^{9}$ Geographical regions are excluded as they are collinear with the independent variable (North/South migration).

10 A large proportion of graduates who migrate for study remain in the North of Italy after graduation.

11 Women outnumber men in higher education in Italy (Cammelli \& Gasperoni, 2015) and the descriptive statistics of the sample show that women are overrepresented in Psychology and Political Science/Social Science while underrepresented in Engineering and Natural Science/Mathematics/Physics.

12 The geographical mobility of medical graduates is constrained by the admission system and their placement on the labour market.
} 
Table 1 Descriptive statistics of Southern Italian graduates by migration behaviour $(N=11,192)$

\begin{tabular}{|c|c|c|c|c|c|}
\hline \multirow[t]{2}{*}{ Covariate } & \multicolumn{5}{|c|}{ Row percentages of total sample } \\
\hline & Stayers & Migration study & Migration work & No & $\%$ \\
\hline \multicolumn{6}{|l|}{ Gender } \\
\hline Women & 52.1 & 30.9 & 17.0 & 6835 & 61.0 \\
\hline Men & 47.0 & 33.9 & 19.1 & 4357 & 38.9 \\
\hline \multicolumn{6}{|l|}{ Parental education } \\
\hline Both with higher education & 41.8 & 40.8 & 17.4 & 1305 & 11.7 \\
\hline At least one with higher education & 48.1 & 35.6 & 16.1 & 2064 & 18.4 \\
\hline At least one with high school & 49.2 & 32.0 & 18.8 & 4998 & 44.7 \\
\hline Both with less than high school & 57.1 & 25.3 & 17.6 & 2825 & 25.2 \\
\hline \multicolumn{6}{|l|}{ Field of study } \\
\hline Agriculture & 59.4 & 24.7 & 15.9 & 227 & 2.0 \\
\hline Architecture & 62.0 & 26.3 & 11.7 & 769 & 7.0 \\
\hline Chemistry/pharmacy & 56.0 & 25.2 & 18.8 & 693 & 6.2 \\
\hline Economics/statistics & 52.5 & 31.0 & 16.5 & 1413 & 12.6 \\
\hline Sports science/ physical education & 50.8 & 41.5 & 7.7 & 130 & 1.2 \\
\hline Biology/geography & 54.2 & 29.4 & 16.4 & 513 & 4.6 \\
\hline Law & 59.3 & 28.9 & 11.8 & 1195 & 10.7 \\
\hline Engineering & 37.1 & 34.5 & 28.4 & 1616 & 14.4 \\
\hline Education & 56.0 & 12.6 & 31.4 & 751 & 6.7 \\
\hline Literature & 45.6 & 37.6 & 16.8 & 636 & 5.6 \\
\hline Linguistics & 44.3 & 35.7 & 20.0 & 512 & 4.5 \\
\hline Medicine & 59.7 & 28.6 & 11.7 & 419 & 3.7 \\
\hline Political science/ social science & 40.8 & 47.4 & 11.8 & 1242 & 11.1 \\
\hline Psychology & 49.2 & 42.0 & 8.8 & 780 & 6.9 \\
\hline Natural science/mathematics/physics & 48.0 & 17.6 & 34.4 & 296 & 2.8 \\
\hline \multicolumn{6}{|l|}{ Degree type } \\
\hline 5 and 6 years & 59.9 & 26.1 & 14.0 & 2687 & 24.2 \\
\hline $3+2$ years & 47.6 & 35.0 & 17.4 & 8505 & 75.8 \\
\hline \multicolumn{6}{|l|}{ Grades university } \\
\hline$[66.100]$ & 46.7 & 39.2 & 14.0 & 1566 & 14.0 \\
\hline [101.110] & 49.3 & 34.6 & 16.0 & 5037 & 45.0 \\
\hline [110 cum laude] & 52.1 & 26.1 & 21.8 & 4589 & 41.0 \\
\hline \multicolumn{6}{|l|}{ High school } \\
\hline Classical "Liceo" & 47.4 & 38.4 & 14.2 & 2238 & 20.0 \\
\hline Scientific “Liceo" & 47.5 & 34.5 & 18.0 & 4813 & 42.6 \\
\hline Other "Liceo" & 54.7 & 24.9 & 20.3 & 895 & 8.0 \\
\hline Technical & 57.0 & 23.7 & 19.3 & 2686 & 24.3 \\
\hline Vocational, other and foreign & 43.7 & 37.1 & 19.2 & 560 & 5.1 \\
\hline Mean high school grades (Std. Dev.) & $84.5(15.4)$ & $86.6(13.4)$ & $87.2(14.6)$ & & \\
\hline \multicolumn{6}{|l|}{ Occupation } \\
\hline Professional and managerial & 49.6 & 31.0 & 19.4 & 7051 & 62.7 \\
\hline Others & 51.0 & 33.8 & 15.2 & 4141 & 37.3 \\
\hline Mean income (Std. Dev.) & $1112.9(581.0)$ & $1327.6(575.4)$ & $1431.0(421.7)$ & & \\
\hline Total & 50.1 & 32.0 & 17.9 & 11,192 & \\
\hline
\end{tabular}

Source: AlamaLaurea data set, 2010 graduate cohort 
variable $Y_{i j}$ was constructed that has $1,2, \ldots, J$ outcomes and takes the value 1 when individual $i$ 's responses is in one of the $\mathrm{j}$ categories and 0 otherwise. The model is estimated in $J-1$ equations:

$$
\log \left(\frac{\operatorname{Pr}\left\{Y_{i j=j \mid X_{i}}\right.}{\operatorname{Pr}\left\{Y_{i j=1 \mid X_{i}}\right.}\right)=X_{i} \beta_{j}
$$

where $X_{i}$ is a vector of independent variables (parental education, field of study, degree type, secondary school, grades secondary school, age, gender, regions from South of Italy) and $\beta_{j}$ is a vector of regression coefficients for the $J$ outcomes.

To answer the second question, the effect of parental education on income mediated by migration for study, linear probability models are estimated. The use of a linear probability model is justified by logging the income variable, to obtain an approximately symmetrical (normal) distribution. Moreover, the models provide robust standard errors to account for heteroscedasticity (Angrist \& Pischke, 2009). The baseline model (Model 1) studies the association between logged income $\left(Y_{i}\right)$ and parental education, controlling for covariates:

$$
\begin{aligned}
\log \left(Y_{i}\right)= & \beta_{0}+\beta_{1} \text { parental education }_{i}+\beta_{2} \text { field of study }_{i} \\
& +\beta_{3} \text { degree type }_{i}+\beta_{4} \text { grades university }_{i} \\
& +\beta_{5} \text { secondaryschool }_{i} \beta_{6} \text { gradessecondaryschool }_{i} \\
& +\beta_{7} \text { age }_{i}+\beta_{8} \text { gender }_{i}+\varepsilon_{i}
\end{aligned}
$$

Based on Eq. 2, the next model also accounts for migration for study (Model 2) as it allows to analyse whether migration for study mediates (part of) the effect of social origins on income. To estimate access to professional and managerial occupations, the analysis relies on a logistic regression model with control variables (Model 1) and a subsequent model accounting also for migration for study (Model 2). To consider individuals' selection into migration, in predicting income and occupations, the analysis accounts for migrants' demographics and educational trajectory (variables included in Eq. 1).

\section{Analysis and results}

\section{Social origins and migration behaviour}

Two sets of results are presented. First, this paper examines the effect of social origins on the graduates' migration behaviour. Second, it scrutinizes whether migration for study mediates the effect of social origins on income and occupations. Therefore, it assesses whether internal migration could be considered a strategy of status maintenance for individuals from privileged backgrounds.

The results reported in Table 2 (in the Appendix) show that social origins, measured by parental education, is a relevant predictor in the graduates' migration for study. More precisely, graduates from a privileged background are more likely to migrate for study than graduates from a less privileged background. Figure 3 plots the marginal changes in predicted probabilities based on the results from Table 2.

As shown in Fig. 3, parental education is thus a "push" factor on graduates' probability to migrate for study. Compared to graduates who have both parents with a higher education degree, graduates who have both parents with less than high school degree or at 

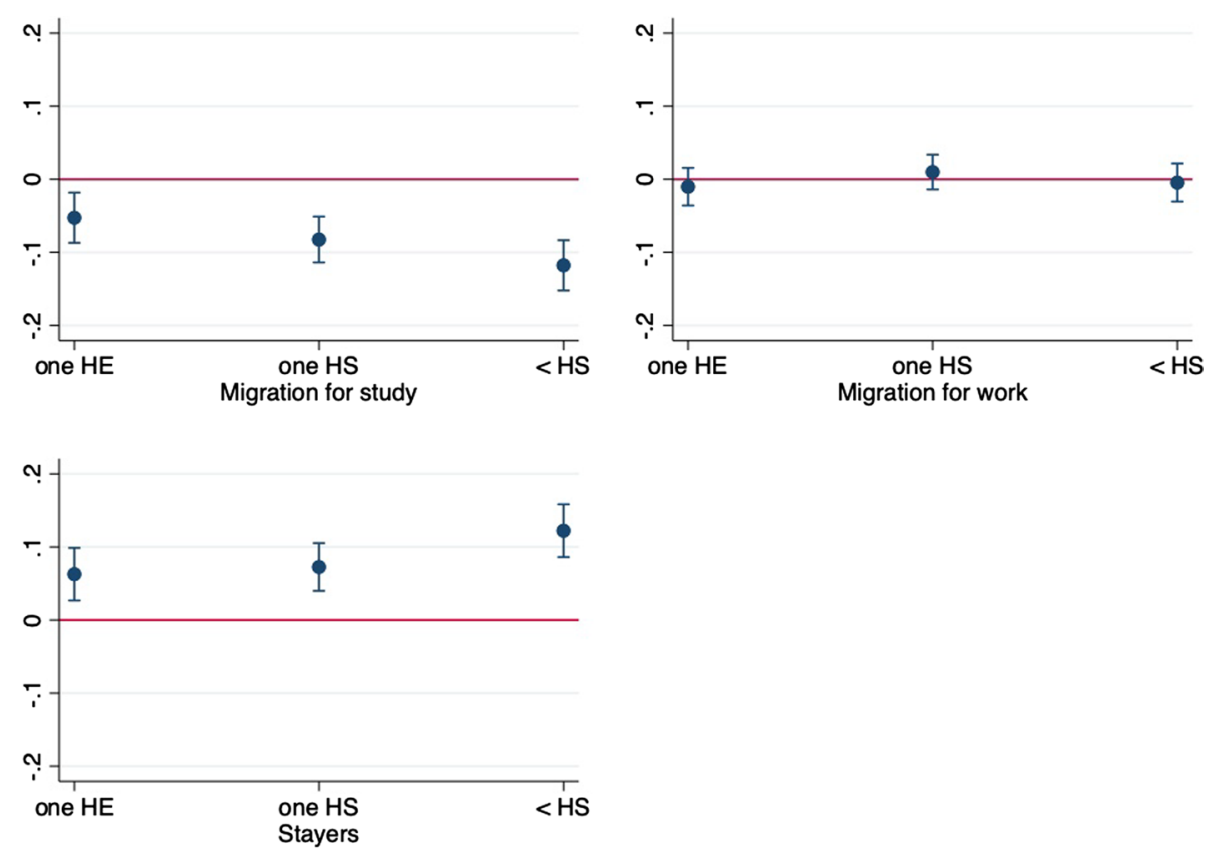

Fig. 3 Marginal changes in predicted migration behaviour as a function of parental education. Bars denote 95\% confidence intervals; both $\mathrm{HE}=$ both parents with a higher education degree (reference); one $\mathrm{HE}=$ one parent with a higher education degree; one $\mathrm{HS}=$ one parent with a high school degree; $<\mathrm{HS}=$ both parents with less than a high school degree. Controls included in the models

least one parent with a high school degree are, about 12 percentage-points, and respectively, 9 percentage-points less likely to migrate for study. Moreover, graduates who have just one parent with a higher education degree, compared to two highly educated parents, are still about 5 percentage-points less likely to migrate for study. This finding is in line with hypothesis $\mathrm{H} 1$ considering migration for study as individuals from a privileged background are more likely to migrate, compared to the individuals from a less privileged background.

Figure 3 also shows no statistically significant difference in the probability to migrate for work by parental background. Hence, hypothesis $\mathrm{H} 1$ in the case of migration for work must be rejected. Moreover, graduates who have less educated parents, compared to the graduates with more educated parents, are more likely to remain in the region of origin (i.e., the mirror image of effects of migration for study).

Besides the effect of social origins, the field of study is another major factor that is associated with individuals' migration decisions (Table 2 in the Appendix). There are substantive differences in migration for study between graduates across fields of study. Graduates from Engineering, Literature, Linguistics, Political Science/Social Science, and, Psychology have the highest propensity to migrate for study compared to law graduates. When it comes to migration for work, graduates from almost all fields of study have a have a higher probability of migrating than law graduates. Graduates from technical fields of study (Engineering, Economics/Statistics, Chemistry/Pharmacy, Biology/ Geography and Natural Science/Mathematics/Physics) and humanities (Literature, 


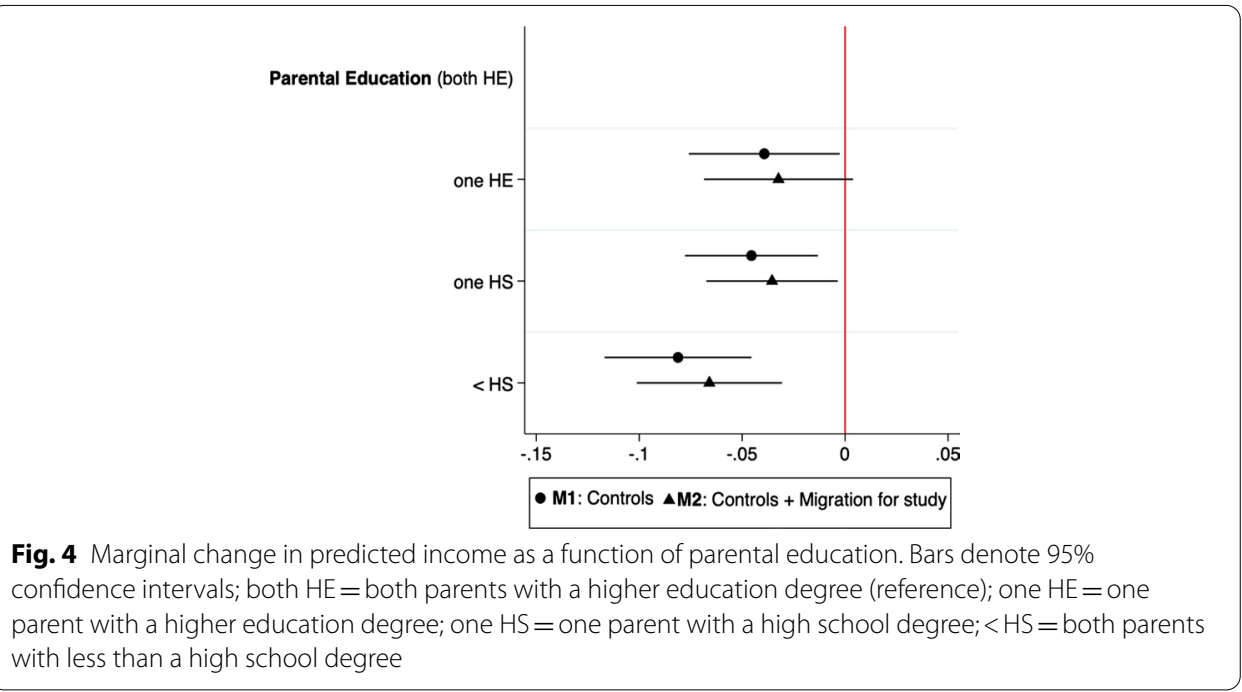

Linguistics) have the highest propensity to migrate for work, compared to the law graduates. ${ }^{13}$ Moreover, compared to men, women are less likely to migrate both for study and for work and this seems to reinforce the idea that also in the case of graduates, migration is a gendered phenomenon.

\section{Internal migration and occupational trajectories \\ Income}

The first part of the analysis showed that individuals' propensity of migration for study is stratified by social origins. Building on this finding, the next analysis scrutinises to what extent migration for study mediates the effect of social origins on graduates' income (Table 3 in the Appendix). Figure 4 displays graduates' income (log transformed) as a function of parental education 5 years after graduation.

The baseline model shows a significant association between parental education and graduates' income even when controls are included in the analysis. More precisely, compared to graduates whose parents both have a higher education degree, graduates whose parents both have less than a high school degree have a penalty of around 8 percent in income. This means that a graduate with two highly educated parents earns on average 116 euros per month or 1392 EUR per year more than a graduate whose parents both have less than a high school degree. Moreover, compared to graduates whose parents both have a higher education degree, graduates who have one parent with a high school degree have around 4 percent income penalty. Furthermore,

\footnotetext{
${ }^{13}$ Law graduates have the lowest probability of migration and one potential explanation is that lawyers is one of the occupational categories with the highest intergenerational transmission of inequality at least in Italy (Raitano \& Vona, 2021). Therefore, considering the importance of family background not only for admission to the university but also later on the labour market, law graduates might perceive migration as a less attractive option, compared to graduates from other fields of study.
} 

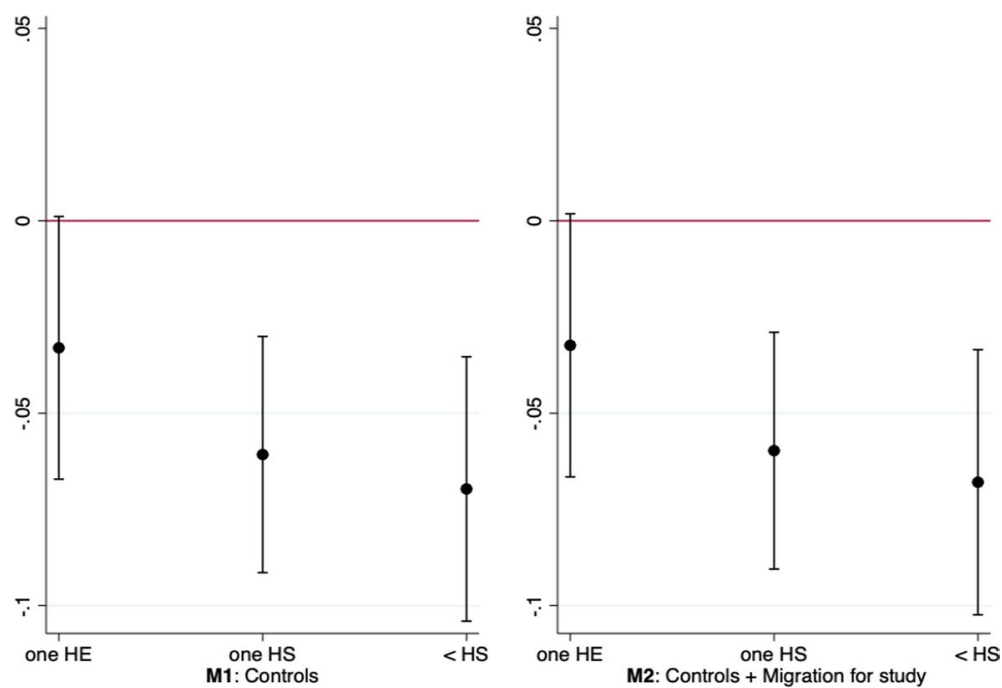

Fig. 5 Marginal change in predicted access to professional and managerial occupations as a function of parental education (ref. both $\mathrm{HE}$ ). Bars denote $95 \%$ confidence intervals; both $\mathrm{HE}=$ both parents with a higher education degree (reference); one $\mathrm{HE}=$ one parent with a higher education degree; one $\mathrm{HS}=$ one parent with a high school degree; $<\mathrm{HS}=$ both parents with less than a high school degree

also graduates who have just one parent with a higher education degree, still face an income penalty of about 3 percent, compared to graduates whose parents both have a higher education degree.

When migration for study is considered (Model 2), the association between parental education and income is reduced by around 2 percent. Compared to the graduates who have both parents with a higher education degree, graduates who have both parents with less than a high school degree have now an income penalty of around 6 percent. Moreover, in the case of graduates who have at least one parent with a high school degree, the income penalty decreases with one percent from the previous model. Furthermore, in the case of the graduates who have just one highly educated parent, the income penalty is no longer significant. Therefore, this indicates that migration for study mediates a part of the effect of social background on income (i.e., hypothesis H3.1. is confirmed in the case of income).

\section{Access to professional and managerial occupations}

Besides income as a measure of occupational success, access to professional and managerial positions (EGP I-II) is considered. Figure 5 displays graduates' access to professional and managerial occupations 5 years after graduation as a function of parental education (probabilities based on Table 4 in the Appendix). 
The baseline model shows an overall association between social origins and graduates' access to professional and managerial occupations. For example, compared to graduates who have both parents with a higher education degree, graduates whose both parents have less than a high school degree have a penalty of around 7 percentage-points in accessing EGP I-II. This disadvantage is reduced to 6 percentage-points in the case that one parent has a high school degree. Figure 5 also shows that the disadvantage is no longer significant in the case of graduates who have one parent with higher education. Accounting for migration to study hardly changes the strength of the association between parental education and access to professional and managerial occupations (Model 2). Hence, this leads to the rejection of hypothesis H3.1. (in the case of occupation) as migration for study does not mediate the association between social origins and occupations.

\section{Discussion}

This paper contributes to the literature on social stratification by analysing the role of internal migration as a possible channel of the intergenerational reproduction of inequality on graduates' occupational outcomes. While the first part of the paper has assessed whether social origins predict the probability of migration for study and work, the second part has scrutinized if internal migration mediates the relationship between social origins and graduates' income and access to professional and managerial occupations.

The findings show that there is a substantial association between graduates' social origins and their propensity to migrate for study. These results suggest that graduates' decision to migrate cannot be perceived solely as an independent choice as it is also influenced by family background (Impicciatore \& Tosi, 2019; Panichella, 2013). Yet, different resources facilitate particular types of migration. Interestingly, findings show that parental education is associated with migration for study but not migration for work. While speculative, this might reflect that parental resources might be required more in the case of migration for study than migration for work. As individuals' educational choices are stratified by social origins, a privileged background ostensibly stimulates graduates' migration for study. Moreover, besides the different educational choices, the financial costs might deter individuals from a less privileged background to migrate for study. In contrast, when it comes to migration for work, these financial costs are reduced and graduates might no longer be as dependent on their family as in the case of migration for study.

Furthermore, the empirical evidence illustrates that migration for study mediates (a part of) the association between social origins and income. Therefore, as individuals from a privileged background have the pressure to achieve a social status at least as high as their parents (Boudon, 1974; Breen \& Goldthorpe, 1997), they might use migration for study as a channel of status maintenance. As a large part of the graduates who migrate for study remain after graduation to work in the North of Italy, migration for study might be a way for facilitating status maintenance in terms of income. Migration for study explains part of the association between social origin and income, but not access to professional and managerial occupations. Therefore, even when individuals 
from a less privileged background "made it" (migrate for study) - considering the challenges related with it-this is not sufficient to compensate for their family background on occupations. Focusing on graduates, this study complements the recent evidence by Ballarino and Panichella (2021) that highlighted that geographical mobility is not sufficient to overcome the obstacles encountered by individuals from a less privileged background in changing the social hierarchy.

A limitation of this paper is that it does not fully address graduates' self-selection into migration. Migration is a choice and migrants are not randomly distributed in the population (Lee, 1966). On average, individuals who migrate are different from individuals who do not migrate on both observable and unobservable characteristics (Ichou, 2014; Impicciatore \& Tosi, 2019; Jaeger et al., 2010). At the same time, this paper uses a rich set of observable controls that accounts for detailed educational trajectory, family background and demographics. Yet, a limitation of the observational cross-sectional data is that it does not permit to consider the effect of unobserved characteristics on the migration decision, such as noncognitive skills, motivation or drive.

Moreover, future research building on these findings can advance our understanding of internal migration as a channel of the intergenerational reproduction of inequality in at least two ways. First, as this paper conceptualized social origins as parental education, further research might focus on parental occupations or social status to capture the complexity of social origin (Bukodi \& Goldthorpe, 2013) in the migration process. Second, employing a longitudinal perspective could serve to measure the returns of migration across different social background groups in the later stage of the graduates' careers. While focusing on graduates at the early stage is relevant as the first years represent the stepping stone in their career, the returns to migration might materialize more strongly later.

Migration for study represents an opportunity for social mobility, yet, this opportunity is substantially stratified by social origins. Individuals from a privileged background are more likely to migrate for study, therefore, to enhance either their educational or labour market opportunities. Thus, migration for study might be a channel of status maintenance for individuals from a privileged background, contributing to the intergenerational income persistence on the labour market. Individuals from less privileged backgrounds are confined both by the poor regional socioeconomic development of the South of Italy and by their social background in improving their life chances in terms of education or work opportunities. Therefore, they might escape geography, but the intergenerational reproduction mechanisms persist.

\section{Appendix}

See Tables 2, 3, 4 and Fig. 6. 
Table 2 Probabilities of migrating to study and work related to stayers

\begin{tabular}{|c|c|c|c|c|c|c|}
\hline & \multicolumn{3}{|c|}{ Migration for study vs. stayers } & \multicolumn{3}{|c|}{ Migration for work vs. stayers } \\
\hline & Estimate & S.E & $p$ value & Estimate & S.E & $p$ value \\
\hline \multicolumn{7}{|l|}{ Parental education } \\
\hline \multicolumn{7}{|l|}{ Both with higher education (ref) } \\
\hline At least one with higher education & 0.758 & 0.061 & 0.001 & 0.823 & 0.086 & 0.062 \\
\hline One with high school & 0.677 & 0.050 & 0.000 & 0.912 & 0.085 & 0.329 \\
\hline Both less than high school & 0.546 & 0.045 & 0.000 & 0.764 & 0.079 & 0.010 \\
\hline \multicolumn{7}{|l|}{ Field of study } \\
\hline \multicolumn{7}{|l|}{ Law (ref) } \\
\hline Agriculture & 0.867 & 0.156 & 0.429 & 1.585 & 0.340 & 0.032 \\
\hline Architecture & 1.068 & 0.119 & 0.554 & 1.111 & 0.167 & 0.484 \\
\hline Chemistry/pharmacy & 1.117 & 0.133 & 0.354 & 1.881 & 0.270 & 0.000 \\
\hline Economics/statistics & 1.186 & 0.132 & 0.124 & 1.632 & 0.240 & 0.001 \\
\hline Sports science and physical education & 1.751 & 0.369 & 0.008 & 0.863 & 0.315 & 0.688 \\
\hline Biology/geography & 1.007 & 0.139 & 0.955 & 1.608 & 0.286 & 0.008 \\
\hline Engineering & 1.462 & 0.165 & 0.001 & 3.733 & 0.540 & 0.000 \\
\hline Education & 0.755 & 0.139 & 0.128 & 1.021 & 0.237 & 0.928 \\
\hline Literature & 1.577 & 0.201 & 0.000 & 2.051 & 0.348 & 0.000 \\
\hline Linguistics & 1.422 & 0.199 & 0.012 & 2.112 & 0.376 & 0.000 \\
\hline Medicine & 1.102 & 0.147 & 0.464 & 1.122 & 0.206 & 0.531 \\
\hline Political science/social science & 2.262 & 0.249 & 0.000 & 1.491 & 0.233 & 0.011 \\
\hline Psychology & 1.698 & 0.206 & 0.000 & 0.947 & 0.173 & 0.767 \\
\hline Natural science/mathematics/physics & 0.705 & 0.133 & 0.066 & 3.727 & 0.684 & 0.000 \\
\hline \multicolumn{7}{|l|}{ Gender } \\
\hline \multicolumn{7}{|l|}{ Men (ref) } \\
\hline Women & 0.76 & 0.401 & 0.003 & 0.878 & 0.057 & 0.046 \\
\hline Constant & 5.715 & 3.122 & 0.001 & 5.749 & 0.057 & 0.005 \\
\hline$R$-Squared & & & & 0.072 & & \\
\hline N & & & & 11,192 & & \\
\hline
\end{tabular}

Multinomial logistic regression; odds ratio; All models control also for: age, degree type, secondary school, grades secondary school, geographical regions 
Table 3 Predicting graduates' income 5 years after graduation

\begin{tabular}{|c|c|c|c|c|c|c|}
\hline & \multicolumn{3}{|c|}{ Model 1 baseline } & \multicolumn{3}{|c|}{ Model $2+$ migration for study } \\
\hline & Estimate & S.E & $p$ value & Estimate & S.E & $p$ value \\
\hline \multicolumn{7}{|l|}{ Parental education } \\
\hline \multicolumn{7}{|l|}{ Both with higher education (ref) } \\
\hline At least one with higher educated & -0.040 & 0.018 & 0.036 & -0.032 & 0.018 & 0.080 \\
\hline At least one with high school & -0.050 & 0.016 & 0.006 & -0.035 & 0.016 & 0.029 \\
\hline Both with less than high school & -0.081 & 0.018 & 0.000 & -0.065 & 0.017 & 0.000 \\
\hline Migration study & & & & 0.154 & 0.010 & 0.000 \\
\hline \multicolumn{7}{|l|}{ Field of study } \\
\hline \multicolumn{7}{|l|}{ Law (ref) } \\
\hline Agriculture & 0.137 & 0.040 & 0.001 & 0.133 & 0.040 & 0.001 \\
\hline Architecture & 0.075 & 0.029 & 0.010 & 0.062 & 0.029 & 0.032 \\
\hline Chemistry and pharmacy & 0.399 & 0.024 & 0.000 & 0.401 & 0.024 & 0.000 \\
\hline Economics/statistics & 0.304 & 0.027 & 0.000 & 0.299 & 0.027 & 0.000 \\
\hline Sports science and physical education & -0.179 & 0.053 & 0.001 & -0.204 & 0.053 & 0.000 \\
\hline Biology and geography & 0.161 & 0.034 & 0.000 & 0.155 & 0.034 & 0.000 \\
\hline Engineering & 0.486 & 0.026 & 0.000 & 0.479 & 0.026 & 0.000 \\
\hline Education & -0.038 & 0.041 & 0.362 & -0.038 & 0.041 & 0.354 \\
\hline Literature & 0.026 & 0.032 & 0.414 & -0.007 & 0.032 & 0.829 \\
\hline Linguistics & 0.119 & 0.034 & 0.001 & 0.109 & 0.034 & 0.002 \\
\hline Medicine & 0.455 & 0.034 & 0.000 & 0.443 & 0.034 & 0.000 \\
\hline Political science/social science & 0.180 & 0.028 & 0.000 & 0.150 & 0.028 & 0.000 \\
\hline Psychology & -0.148 & 0.032 & 0.000 & -0.168 & 0.032 & 0.000 \\
\hline Natural science/mathematics/physics & 0.358 & 0.036 & 0.000 & 0.371 & 0.036 & 0.000 \\
\hline \multicolumn{7}{|l|}{ Gender } \\
\hline \multicolumn{7}{|l|}{ Men (ref) } \\
\hline Women & -0.195 & 0.011 & 0.000 & -0.190 & 0.011 & 0.000 \\
\hline Constant & 7.800 & 0.112 & 0.000 & 7.668 & 0.112 & 0.000 \\
\hline$R$-Squared & 0.195 & & & 0.210 & & \\
\hline$N$ & 11,192 & & & 11,192 & & \\
\hline
\end{tabular}

Linear probability models with robust standard error; All models control also for: age, degree type, secondary school, grades secondary school,grades university 
Table 4 Predicting graduates' access to professional and managerial occupations 5 years after graduation

\begin{tabular}{|c|c|c|c|c|c|c|}
\hline & \multicolumn{3}{|c|}{ Model 1 baseline } & \multicolumn{3}{|c|}{ Model $2+$ migration study } \\
\hline & Estimate & S.E & $p$ value & Estimate & S.E & $p$ value \\
\hline \multicolumn{7}{|l|}{ Parental education } \\
\hline \multicolumn{7}{|l|}{ Both with higher education (ref) } \\
\hline At least one with education & -0.160 & 0.085 & 0.060 & -0.157 & 0.085 & 0.066 \\
\hline At least one with high school & -0.287 & 0.077 & 0.000 & -0.282 & 0.077 & 0.000 \\
\hline Both with less than high school & -0.327 & 0.084 & 0.000 & -0.319 & 0.084 & 0.000 \\
\hline Migration study & & & & 0.086 & 0.048 & 0.072 \\
\hline \multicolumn{7}{|l|}{ Field of Study } \\
\hline \multicolumn{7}{|l|}{ Law (ref) } \\
\hline Agriculture & -0.268 & 0.168 & 0.111 & -0.276 & 0.168 & 0.102 \\
\hline Architecture & 0.229 & 0.124 & 0.065 & 0.218 & 0.124 & 0.080 \\
\hline Chemistry and pharmacy & 0.416 & 0.151 & 0.006 & 0.414 & 0.151 & 0.006 \\
\hline Economics/statistics & -0.897 & 0.104 & 0.000 & -0.904 & 0.105 & 0.000 \\
\hline Sports science and physical education & -1.293 & 0.214 & 0.000 & 1.311 & 0.214 & 0.000 \\
\hline Biology and Geography & 0.244 & 0.131 & 0.062 & 0.236 & 0.131 & 0.071 \\
\hline Engineering & 0.570 & 0.109 & 0.000 & 0.563 & 0.109 & 0.000 \\
\hline Education & -1.336 & 0.166 & 0.000 & -1.341 & 0.166 & 0.000 \\
\hline Literature & -0.366 & 0.120 & 0.002 & -0.381 & 0.121 & 0.002 \\
\hline Linguistics & -0.555 & 0.129 & 0.000 & -0.566 & 0.129 & 0.000 \\
\hline Medicine & -0.555 & 0.136 & 0.000 & -0.567 & 0.136 & 0.000 \\
\hline Political science/social science & -1.150 & 0.107 & 0.000 & -1.171 & 0.107 & 0.000 \\
\hline Psychology & -0.042 & 0.116 & 0.717 & -0.058 & 0.116 & 0.618 \\
\hline Natural science/mathematics/physics & 0.444 & 0.158 & 0.005 & 0.448 & 0.158 & 0.005 \\
\hline \multicolumn{7}{|l|}{ Gender } \\
\hline \multicolumn{7}{|l|}{ Men (ref) } \\
\hline Women & -0.205 & 0.051 & 0.000 & -0.202 & 0.051 & 0.000 \\
\hline Constant & 5.802 & 0.676 & 0.000 & 5.711 & 0.678 & 0.000 \\
\hline$R$-Squared & 0.163 & & & 0.164 & & \\
\hline$N$ & 11,192 & & & 11,192 & & \\
\hline
\end{tabular}

Logistic regression models; All models control also for: age, degree type, secondary school, grades secondary school, grades university 


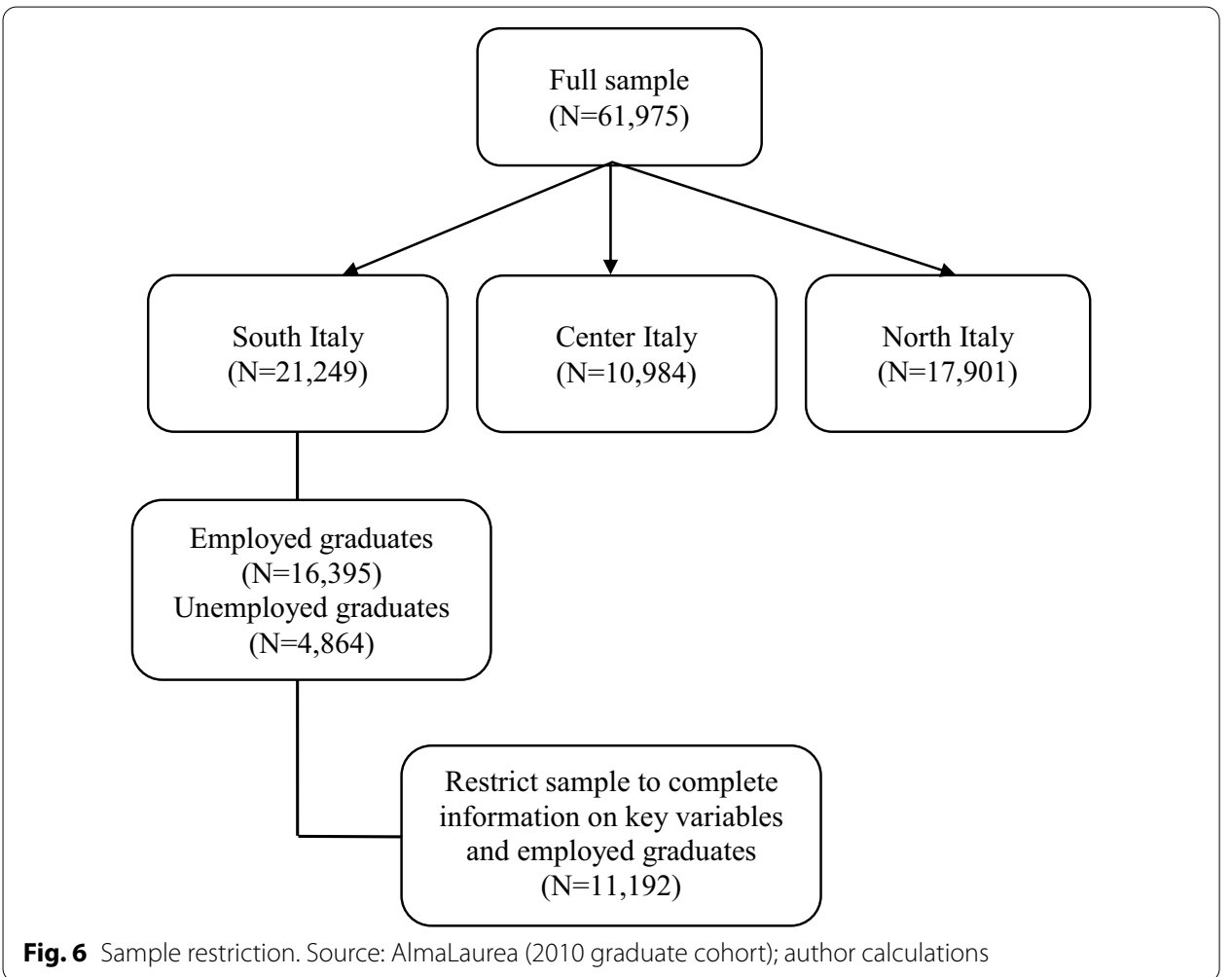

\section{Acknowledgements}

I would like to thank the reviewers and the editor for their constructive feedback. For comments on previous versions of this paper, I would like to thank Nevena Kulic, Peter Thisted Dinesen and Mathieu Ichou. I would also like to thank the AlmaLaurea team, especially Davide Cristofori for data access and useful guidance.

\section{Authors' contributions}

Single-authored paper. The author read and approved the final manuscript.

\section{Funding}

Open Access funding enabled and organized by Projekt DEAL.

Availability of data and materials

Access to data is restricted but can be obtained on-site in the AlamaLaurea office (Bologna, Italy).

\section{Declarations}

\section{Competing interests}

Not applicable.

Received: 15 December 2020 Accepted: 31 January 2022

Published online: 24 February 2022

\section{References}

Aina, C., \& Pastore, F. (2012). Delayed graduation and overeducation: a test of the human capital model versus the screening hypothesis. 6413, 31

AlmaLaurea. (2014). Scienze strategiche e militari. AlmaLaurea.

Ambrosini, M. (2005). Sociologia delle migrazioni. II Mulino.

Angrist, J. D., \& Pischke, J.-S. (2009). Mostly harmless econometrics: an empiricist's companion. Princeton University Press. Arango, J. (2000). Explaining migration: a critical view. International Social Science Journal, 52(165), 283-296. https:// doi.org/10.1111/1468-2451.00259

Assirelli, G., Barone, C., \& Recchi, E. (2018). "You Better Move On": determinants and labor market outcomes of graduate migration from Italy. International Migration Review. https://doi.org/10.1177/0197918318767930 
Attanasio, M., \& Enea, M. (2019). La mobilità degli studenti universitari nell'ultimo decennio in Italia. In G. De Santis, E. Pirani, \& M. Porcu (Eds.), Rapporto sulla popolazione: Listruzione in Italia (pp. 43-59). II Mulino.

Bagnasco, A. (1997). Tre Italie: la problematica territoriale dello sviluppo italiano. II Mulino.

Ballarino, G., \& Panichella, N. (2021). Social origins, geographical mobility and occupational attainment in contemporary Italy. Genus, 77(1), 3. https://doi.org/10.1186/s41118-020-00112-4

Barbieri, P. (2003). Social capital and self-employment: a network analysis experiment and several considerations. International Sociology, 18(4), 681-701. https://doi.org/10.1177/0268580903184003

Bernardi, F., \& Ballarino, G. (2016). Education, occupation and social origin: a comparative analysis of the transmission of socio-economic inequalities. Edward Elgar Pub.

Black, D. A., \& Smith, J. A. (2004). How robust is the evidence on the effects of college quality? Evidence from matching. Journal of Econometrics, 121(1), 99-124. https://doi.org/10.1016/j.jeconom.2003.10.006

Blau, P. M., \& Duncan, O. D. (1967). The American occupational structure. John Wiley.

Boudon, R. (1974). Education, opportunity, and social inequality: changing prospects in western society. John Wiley \& Sons Canada Limited.

Bourdieu, P. (1984). Distinction: a social critique of the judgement of taste (Reprint1984 ed.). Harvard University Press.

Breen, R., \& Goldthorpe, J. H. (1997). Explaining educational differentials: towards a formal rational action theory. Rationality and Society, 9(3), 275-305. https://doi.org/10.1177/104346397009003002

Brunello, G., \& Cappellari, L. (2008). The labour market effects of Alma Mater: evidence from Italy. Economics of Education Review, 27(5), 564-574. https://doi.org/10.1016/j.econedurev.2007.05.004

Bukodi, E., \& Goldthorpe, J. H. (2013). Decomposing 'Social Origins': the effects of parents' class, status, and education on the educational attainment of their children. European Sociological Review, 29(5), 1024-1039. https://doi.org/10. 1093/esr/jcs079

Cammelli, A., \& Gasperoni, G. (2015). Opportunities and challenges for higher education in Italy. AlamaLaurea Working Papers, No 74, Bologna.

Capuano, S. (2012). The south-north mobility of Italian college graduates an empirical analysis. European Sociological Review, 28(4), 538-549. https://doi.org/10.1093/esr/jcr023

Carling, J. (2002). Migration in the age of involuntary immobility: theoretical reflections and Cape Verdean experiences. Journal of Ethnic and Migration Studies, 28(1), 5-42. https://doi.org/10.1080/13691830120103912

Carling, J., \& Schewel, K. (2018). Revisiting aspiration and ability in international migration. Journal of Ethnic and Migration Studies, 44(6), 945-963. https://doi.org/10.1080/1369183X.2017.1384146

Chevalier, A., \& Conlon, G. (2003). Does it pay to attend a prestigious university? [Monograph]. IZA Discussion Paper No.848

Ciriaci, D. (2005). La fuga del capitale umano qualificato dal Mezzogiorno: un catching-up sempre più difficile. Rivista Economica Del Mezzogiorno. https://doi.org/10.1432/21198

Ciriaci, D. (2014). Does university quality influence the interregional mobility of students and graduates? The case of Italy. Regional Studies, 48(10), 1592-1608. https://doi.org/10.1080/00343404.2013.821569

D'Agostino, A., Ghellini, G., \& Longobardi, S. (2019). Out-migration of university enrolment: the mobility behaviour of Italian students. International Journal of Manpower, 40(1), 56-72. https://doi.org/10.1108/IJM-07-2017-0169

DaVanzo, J. (1981). Repeat migration, information costs, and location-specific capital. Population and Environment, 4(1), 45-73. https://doi.org/10.1007/BF01362575

Di Stasio, V., \& Gërxhani, K. (2015). Employers' social contacts and their hiring behavior in a factorial survey. Social Science Research, 51, 93-107. https://doi.org/10.1016/j.ssresearch.2014.12.015

Dotti, N. F., Fratesi, U., Lenzi, C., \& Percoco, M. (2013). Local labour markets and the interregional mobility of Italian university students. Spatial Economic Analysis, 8(4), 443-468. https://doi.org/10.1080/17421772.2013.833342

Erikson, R., \& Goldthorpe, J. H. (1992). The constant flux: a study of class mobility in industrial societies. Oxford University Press.

Erikson, R., \& Jonsson, J. O. (1998). Social origin as an interest-bearing asset: family background and labour-market rewards among employees in Sweden. Acta Sociologica, 41(1), 19-36.

Faini, R., Galli, G., Gennari, P., \& Rossi, F. (1997). An empirical puzzle: falling migration and growing unemployment differentials among Italian regions. European Economic Review, 41(3), 571-579. https://doi.org/10.1016/S0014-2921(97) 00023-8

Fields, G. S. (1976). Labor force migration, unemployment and job turnover. The Review of Economics and Statistics, 58(4), 407-415. https://doi.org/10.2307/1935872

Gambetta, D. (1987). Were they pushed or did they jump? Individual decision mechanisms in education. Cambridge University Press. https://doi.org/10.1017/CBO9780511735868

Ichou, M. (2014). Who they were there: immigrants' educational selectivity and their children's educational attainment. European Sociological Review, 30(6), 750-765. https://doi.org/10.1093/esr/jcu071

Impicciatore, R., \& Tosi, F. (2019). Student mobility in Italy: the increasing role of family background during the expansion of higher education supply. Research in Social Stratification and Mobility. https://doi.org/10.1016/j.rssm.2019.100409

Impicciatore, R., \& Tuorto, D. (2011). Mobilità interna e istruzione universitaria: Risorse familiari, individuali e opportunità di ascesa sociale nell'occupazione. Sociologia Del Lavoro. https://doi.org/10.3280/SL2011-121004

Jaeger, D. A., Dohmen, T., Falk, A., Huffman, D., Sunde, U., \& Bonin, H. (2010). Direct evidence on risk attitudes and migration. Review of Economics and Statistics, 92(3), 684-689. https://doi.org/10.1162/REST_a_00020

Kahanec, M., \& Fabo, B. (2013). Migration strategies of crisis-stricken youth in an enlarged European Union. Transfer European Review of Labour and Research, 19(3), 365-380. https://doi.org/10.1177/1024258913493701

Kahneman, D., \& Tversky, A. (1984). Choices, values, and frames. American Psychologist, 39(4), 341-350.

Lee, E. S. (1966). A theory of migration. Demography, 3(1), 47-57. https://doi.org/10.2307/2060063

Lucas, S. R. (2001). Effectively maintained inequality: education transitions, track mobility, and social background effects. American Journal of Sociology, 106(6), 1642-1690. https://doi.org/10.1086/321300

Mocetti, S., \& Porello, C. (2010). How does immigration affect native internal mobility? New evidence from Italy. Regional Science and Urban Economics, 40(6), 427-439. https://doi.org/10.1016/j.regsciurbeco.2010.05.004. 
Panichella, N. (2013). Migration strategies and occupational outcomes of southern Italian graduates. Journal of Modern Italian Studies, 18(1), 72-89. https://doi.org/10.1080/1354571X.2013.730274

Piras, R. (2005). Il contenuto di capitale umano dei flussi migratori interregionali: 1980-2002. Politica Economica. https:// doi.org/10.1429/20830

Raitano, M., \& Vona, F. (2021). Nepotism vs. specific skills: the effect of professional liberalization on returns to parental background of Italian lawyers. Journal of Economic Behavior \& Organization, 184, 489-505. https://doi.org/10.1016/j. jebo.2021.02.009

Recchi, E. (2015). Mobile Europe: the theory and practice of free movement in the EU

De Rita, G. (2002). La condizione del Mezzogiorno- ieri, oggi e domani- vista da un sociologo. (No. 16; SVIMEZ)

Ruiu, G., Fadda, N., Ezza, A., \& Esposito, M. (2019). Exploring mobility of Italian Ph.Ds over the last decades. Electronic Journal of Applied Statistical Analysis, 12(4), 748-773. https://doi.org/10.1285/i20705948v12n4p748

Smith, D. P., Finney, N., \& Walford, N. (Eds.). (2015). Internal migration: geographical perspectives and processes. Ashgate.

Stark, O., \& Bloom, D. (1985). The New economics of labor migration. The American Economic Review, 75(2), 173-178.

Torche, F. (2011). Is a college degree still the great equalizer? Intergenerational mobility across levels of schooling in the United States. American Journal of Sociology, 117(3), 763-807. https://doi.org/10.1086/661904

White, M. J. (Ed.). (2016). International handbook of migration and population distribution (Vol. 6). Springer.

Wilson, F. D. (1985). Migration and occupational mobility: a research note. International Migration Review, 19(2), 278. https://doi.org/10.2307/2545773

Witteveen, D., \& Attewell, P. (2020). Reconsidering the'meritocratic power of a college degree'. Research in Social Stratification and Mobility, 66, 100479. https://doi.org/10.1016/j.rssm.2020.100479

\section{Publisher's Note}

Springer Nature remains neutral with regard to jurisdictional claims in published maps and institutional affiliations.

\section{Submit your manuscript to a SpringerOpen ${ }^{\circ}$ journal and benefit from:}

- Convenient online submission

- Rigorous peer review

- Open access: articles freely available online

- High visibility within the field

Retaining the copyright to your article

Submit your next manuscript at $\boldsymbol{s p r i n g e r o p e n . c o m ~}$ 